\title{
Cell-based neurorestorative therapy for postpoliomyelitis syndrome: a case report
}

\author{
This article was published in the following Dove Press journal: \\ Journal of Neurorestoratology \\ 8 July 2016 \\ Number of times this article has been viewed
}

\section{Haitao $\mathrm{Xi}^{1,2, *}$ \\ Di Chen ${ }^{1, *}$}

'Center of Neurorestoratology, Beijing Hongtianji Neuroscience Academy, ${ }^{2}$ Center of Neurorestoratology, Beijing Rehabilitation Hospital affiliated Capital Medical University, Beijing, People's Republic of China

*These authors contributed equally to this work
Correspondence: Haitao Xi Beijing Hongtianji Neuroscience Academy, Lingxiu Building, No I at Gucheng, Shijingshan District, Beijing I00I43, People's Republic of China Tel +86 I0 I38 II695976

Email xhtdoctor@I26.com

\begin{abstract}
Postpoliomyelitis syndrome refers to the new neuromuscular symptoms that occur in patients, years after their acute poliomyelitis has stabilized. A 64-year-old Danish man presented with lower limb weakness and severe pain for 2 years and 5 months. He had a history of poliomyelitis affecting his limbs 59 years ago. Physical examination revealed atrophy of muscles of both lower limbs. Electromyography revealed that recruitment of maximal voluntary contraction of muscles was decreased in the affected muscles. He received cell-based neurorestorative therapy during admission, and then, his neurological function improved and remained stable during 4-year follow-up. This case report shows that cell therapy could be a treatment option for postpoliomyelitis syndrome.
\end{abstract}

Keywords: postpoliomyelitis syndrome, neuromuscular disease, cell transplantation, cell-based neurorestorative therapy

\section{Introduction}

Postpoliomyelitis syndrome (PPS) is characterized by the delayed appearance of new neuromuscular symptoms in patients, many years after they are affected with acute poliomyelitis paralysis. Some patients also develop deglutition and breathing difficulty, anxiety, and sleep disorders like periodic limb movements. ${ }^{1}$ The diagnosis is usually based on a typical medical history, electromyographic (EMG) investigation, ${ }^{2}$ and exclusion of other diseases presenting similar features. In 2001, the diagnostic criteria for PPS were brought up at the International Conference of the PPS. Once a clinical diagnosis is established, the therapeutic options can be discussed. Due to lack of specific therapy, rational therapeutic approaches are symptomatic, including exercise, reassurance, and life strategies for fatigue. ${ }^{3}$ Several studies have been conducted to validate medications (pyridostigmine, immunoglobulin, coenzyme Q10), ${ }^{4}$ physical exercise protocols, ${ }^{5}$ or cognitive behavioral therapy. ${ }^{6}$ Also, medications combined with individual and supervised exercise training programs could improve the symptoms in PPS patients. ${ }^{7}$ Right now, there is no specific treatment for PPS. Very few studies have reported some improvement. With rapid development and clinical advancement in neurorestoration, neurorestoratology has become a distinct discipline within neurosciences. ${ }^{8-13}$ Various neurorestorative strategies or therapies have been widely used in clinical practice. Evidence has shown the benefits of cell-based neurorestorative therapy for patients with spinal cord injury, amyotrophic lateral sclerosis, stroke, multiple sclerosis, cerebral palsy, and other refractory nerve diseases. ${ }^{14-19}$ In this paper, we report a case of PPS showing functional improvement following cell-based neurorestorative therapy. 


\section{Case report}

\section{Patient}

A 64-year-old Danish man suffered from bilateral amyotrophic lower limbs with lower limb weakness and severe pain for 2 years and 5 months. He had been infected with polio 59 years ago and then recovered completely without dysfunction. He developed progressive weakness in right leg with pain in August 2007. The same symptoms occurred in the left leg 6 months later, which led to slow walking. He was administered routine treatment and rehabilitation therapy on diagnosis of PPS. On admission (January 12, 2010), he complained weakness of lower extremities and sensory impairment. He had persistent pain on his back and both lower limbs. He was not able to walk normally. He felt respiratory insufficiency when he performed excessive exercise.

Atrophy of muscles of his lower limbs (Figure 1) and hollow-foot deformity (Figure 2) in his feet were noticed. The strength of his arms was five grades bilaterally and of his legs was four grades, except ankle dorsiflexor which showed two grades. Muscle tone of his limbs was normal. The observations on sensation were as follows. Light touch decreased at $\mathrm{L} 1, \mathrm{~L} 4, \mathrm{~L} 5$, and S2 on the right and at L1, L4, S1, and S2 on the left. Light touch disappeared at S1 on the right and L5 on the left. Pin prick disappeared at L4-S2 on the right and at T11 and L3-S2 on the left. Abdominal reflex sign disappeared bilaterally. Triceps reflex and knee jerk tendon reflex were less active than normal in both sides. Babinski sign was positive bilaterally. Heel-to-shin examinations: the examination was completed slowly. Anal sensation and contraction were normal.

Treatment was administered at Beijing Hongtianji Neuroscience Academy in conjunction with Beijing Rehabilitation Hospital affiliated Capital Medical University, in accordance with the guidelines issued by the Chinese Ministry of Health

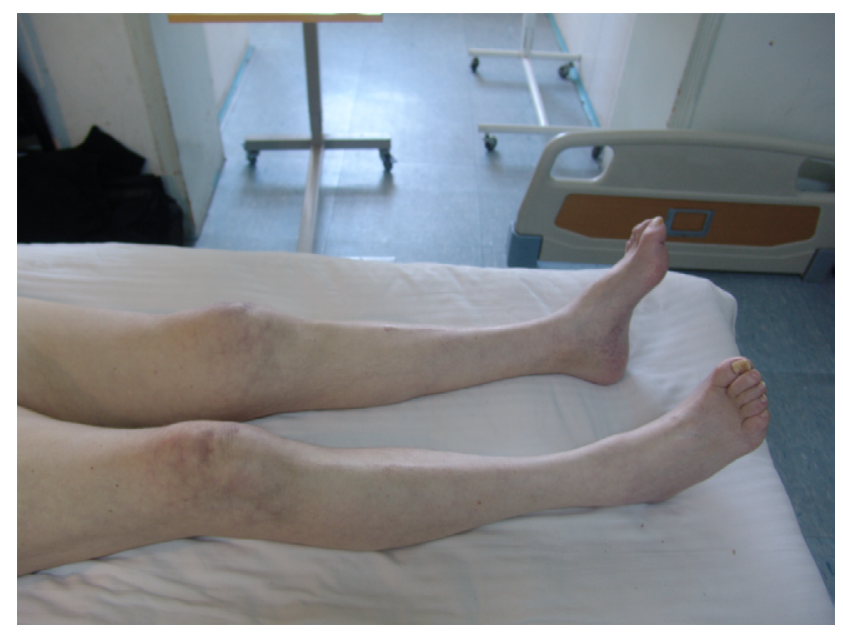

Figure I Atrophy in the patient's muscles of lower limbs.

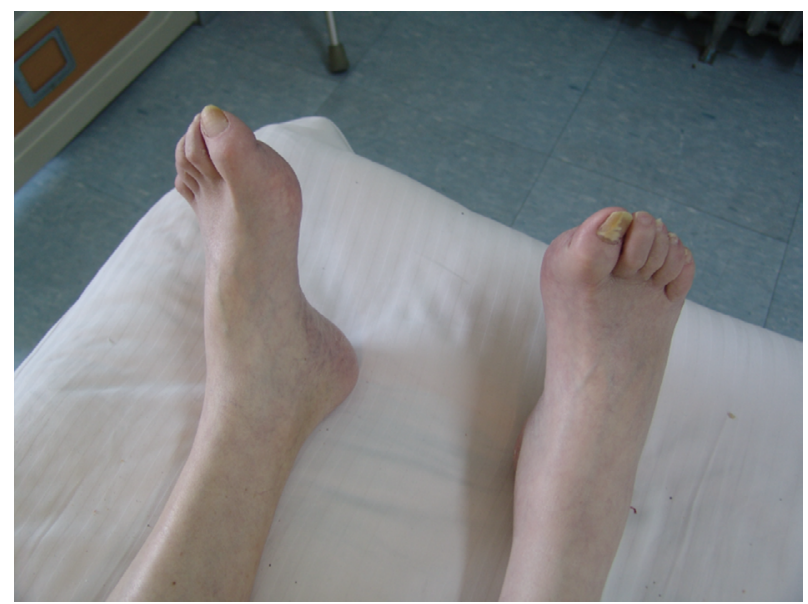

Figure 2 Hollow-foot deformity in the patient's feet.

(91-006) in which functional transplantation can be done according to clinical routine rule. ${ }^{20}$ The study was approved by the research ethics committee of Beijing Hongtianji Neuroscience Academy and Beijing Rehabilitation Hospital affiliated Capital Medical University. The patient was fully informed about the nature of the treatment, and he gave written informed consent to undergo cell-based neurorestorative therapy.

\section{Cell-based neurorestorative therapy}

Cells were isolated and cultured according to Good Manufacturing Practice standard for laboratories, as described previously. ${ }^{21,22}$ In accordance with the Chinese Pharmacopoeia procedure, the testing procedures for bacteria, viruses, fungi, mycoplasma, and endotoxin were carried out. Among the cell quality indicators, the cell activity was $\geq 85 \%$. After the preexamination, the patient received cell therapy as follows: 1$)$ the percutaneous intrathecal (C7-T1) implantation of umbilical cord stromal cells $\left(1.2 \times 10^{7}\right)$ and neural progenitor cells $\left(2 \times 10^{6}\right)$ together with cerebrolysin was done on January 21, 2010. 2) The percutaneous intrathecal (T9-T10) implantation of neural progenitor cells $\left(2 \times 10^{6}\right)$ and Schwann cells $\left(5 \times 10^{5}\right)$ together with cerebrolysin was done on January 25, 2010. 3) The umbilical cord stromal cells $\left(1 \times 10^{7}\right)$ were transfused by intravenous drip on January 29 , 2010. 4) The percutaneous intrathecal (T1-T2) implantation of olfactory ensheathing cells $\left(1 \times 10^{6}\right)$, neural progenitor cells $\left(2 \times 10^{6}\right)$, and bone marrow stromal cells $\left(3 \times 10^{6}\right)$ together with cerebrolysin was performed on February 1, 2010.

\section{Clinical evaluation}

Before cell therapy (January 13, 2010), two independent neurologists examined the patient with the American Spinal Injury Association impairment scale (ASIA) and International Association of Neurorestoratology Spinal Cord Injury Functional 
Table I Motor score of ASIA (before cell-based therapy)

\begin{tabular}{lll}
\hline Muscles & Right side & Left side \\
\hline C5-elbow flexors & 5 & 5 \\
C6-wrist extensors & 5 & 5 \\
C7-elbow extensors & 5 & 5 \\
C8-finger flexors & 5 & 5 \\
TI-finger abductors & 5 & 5 \\
L2-hip flexors & 4 & 4 \\
L3-knee extensors & 4 & 4 \\
L4-ankle dorsiflexors & 4 & 4 \\
L5-long toe extensors & 4 & 4 \\
SI-ankle plantar flexors & 2 & 2 \\
\hline
\end{tabular}

Table 2 Sensory (light touch and pin prick) score of ASIA (before cell-based therapy)

\begin{tabular}{|c|c|c|c|}
\hline \multicolumn{2}{|c|}{ Sensory } & \multirow{2}{*}{$\begin{array}{l}\text { Right side } \\
\text { C2-TI2, L2-L3, } \\
\text { S3-S45 }\end{array}$} & \multirow{2}{*}{$\begin{array}{l}\text { Left side } \\
\text { C2-TI2, L2-L3, } \\
\text { S3-S45 }\end{array}$} \\
\hline $\begin{array}{l}\text { Light } \\
\text { touch }\end{array}$ & $\begin{array}{l}\text { Normal sensation } \\
\text { levels ( } 2 \text { points) }\end{array}$ & & \\
\hline & $\begin{array}{l}\text { Hypoesthesia level } \\
\text { (I point) }\end{array}$ & LI, L4-L5, S2 & LI, L4, SI-S2 \\
\hline & $\begin{array}{l}\text { Anesthesia level } \\
(0 \text { point })\end{array}$ & SI & L5 \\
\hline \multirow[t]{3}{*}{$\begin{array}{l}\text { Pin } \\
\text { prick }\end{array}$} & $\begin{array}{l}\text { Normal sensation level } \\
\text { ( } 2 \text { points) }\end{array}$ & C2-L3, S3-S45 & $\begin{array}{l}\text { C2-TIO, TI2-L2, } \\
\text { S3-S45 }\end{array}$ \\
\hline & $\begin{array}{l}\text { Hypoesthesia level } \\
\text { (I point) }\end{array}$ & - & - \\
\hline & $\begin{array}{l}\text { Anesthesia level } \\
(0 \text { point })\end{array}$ & L4-S2 & TII, L3-S2 \\
\hline
\end{tabular}

Table 3 Motor score of ASIA (after cell-based therapy)

\begin{tabular}{lll}
\hline Muscles & Right side & Left side \\
\hline C5-elbow flexors & 5 & 5 \\
C6-wrist extensors & 5 & 5 \\
C7-elbow extensors & 5 & 5 \\
C8-finger flexors & 5 & 5 \\
TI-finger abductors & 5 & 5 \\
L2-hip flexors & 4 & 4 \\
L3-knee extensors & 5 & 5 \\
L4-ankle dorsiflexors & 5 & 5 \\
L5-long toe extensors & 5 & 4 \\
SI-ankle plantar flexors & 4 & 4 \\
\hline
\end{tabular}

Rating Scale (IANR-SCIFRS). The findings were as follows: ASIA motor $\operatorname{score}^{23}$ (Table 1) was 43 points on the right and 43 points on the left; ASIA light touch score (Table 2) was 50 points on the right and 50 points on the left; ASIA pin prick score (Table 2) was 48 points on the right and 44 points on the left; score of IANR-SCIFRS ${ }^{15,24}$ was 42 points.

At discharge, the patient's neurological function had improved. His general condition was better; power of his legs ameliorated. The ability of standing from bedside and turning over on bed improved. The pain in his back disappeared. The sensation was also better than before.
Table 4 Sensory (light touch and pin prick) score of ASIA (after cell-based therapy)

\begin{tabular}{llll}
\hline Sensory & Right side & Left side \\
\hline Light & Normal sensation levels & C2-TI2, & C2-TI2, L2-S45 \\
touch & (2 points) & L2-S45 & \\
& Hypoesthesia level (I point) & LI & LI \\
& Anesthesia level (0 point) & - & - \\
Pin & Normal sensation level & C2-L3, & C2-TI0, TI2- \\
prick & (2 points) & S2-S45 & L4, SI-S45 \\
& Hypoesthesia level (I point) & - & - \\
& Anesthesia level (0 point) & L4-SI & TII, L5 \\
\hline
\end{tabular}

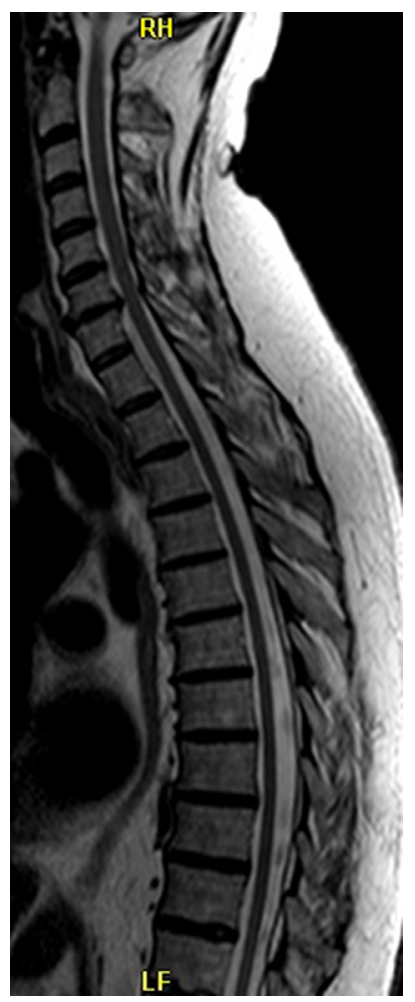

Figure 3 Intervertebral disk hernia at C6/C7.

The neurologists reexamined the patient on February 9, 2010, and the findings were as follows: ASIA motor score (Table 3) was 48 points on the right and 47 points on the left; ASIA light touch score (Table 4) was 55 points on the right and 55 points on the left; ASIA pin prick score (Table 4) was 50 points on the right and 52 points on the left; score of IANR-SCIFRS was 45 points.

\section{Supplementary examinations (magnetic resonance imaging [MRI], EMG, and pulmonary function test) MRI}

MRI of spinal cord showed intervertebral disk hernia at the C6/ C7 level (Figure 3) and atrophic thoracic spinal cord (Figure 4). 


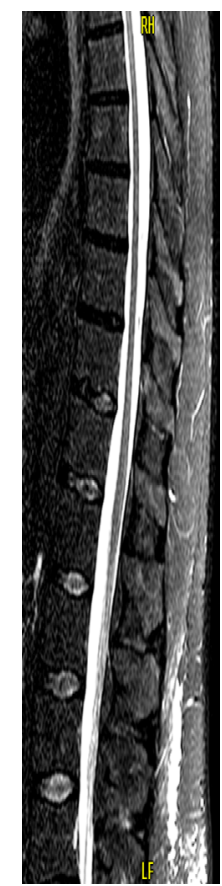

Figure 4 Thoracic spinal cord atrophy.

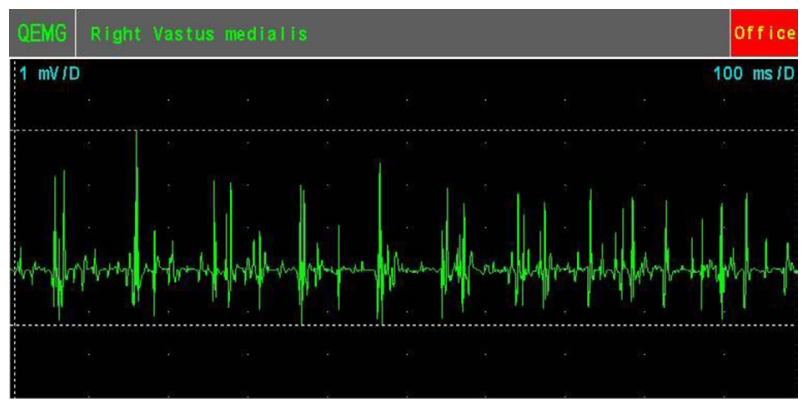

Figure 5 Preoperative recruitment of maximal voluntary contraction in right vastus medialis muscle.

Abbreviation: QEMG, quantitative electromyography.

\section{EMG}

EMG examination on January 13, 2010, before cell-based neurorestorative therapy: the spontaneous potentials could be recorded in all muscles, except deltoid L muscle. The recruitment of maximal voluntary contraction of muscles was normal in deltoid muscles bilaterally and tibialis anterior $\mathrm{R}$ muscle. The recruitment of maximal voluntary contraction of muscles was decreased in other muscles.

EMG examination on February 8, 2010, after cell-based neurorestorative therapy: the recruitment of maximal voluntary contraction was improved and more intensive than preoperative EMG in vastus medialis muscles (Figures 5 and 6), First dorsal interosseus (Ist Dorsal Int) muscles bilaterally (Figures 7 and 8), and tibialis anterior L muscle.

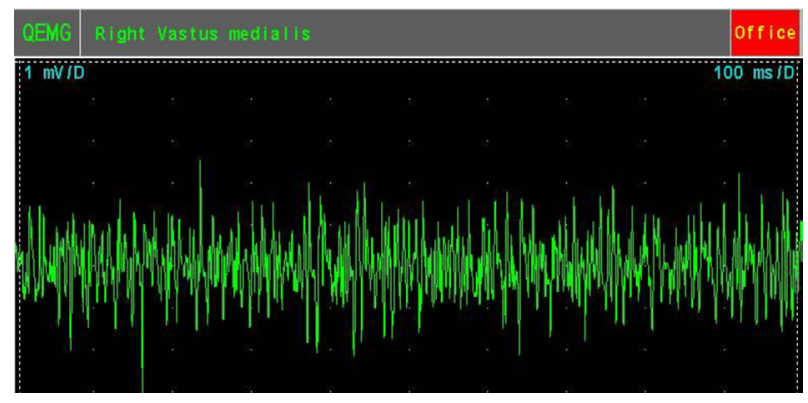

Figure 6 Postoperative recruitment of maximal voluntary contraction in right vastus medialis muscle.

Abbreviation: QEMG, quantitative electromyography.

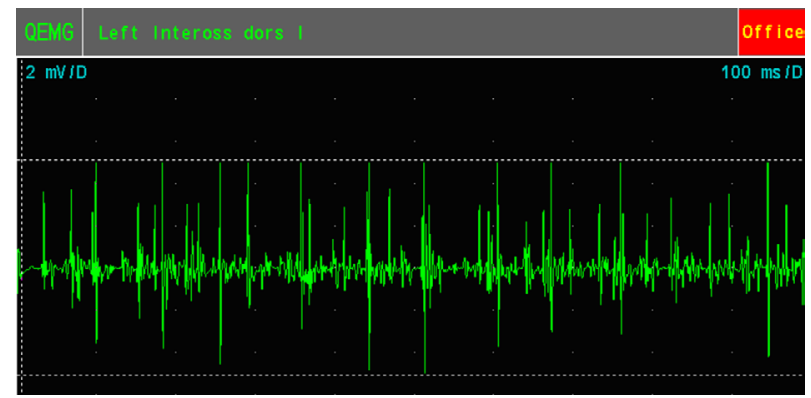

Figure 7 Preoperative recruitment of maximal voluntary contraction in left first Dorsal Int muscles.

Abbreviation: QEMG, quantitative electromyography.

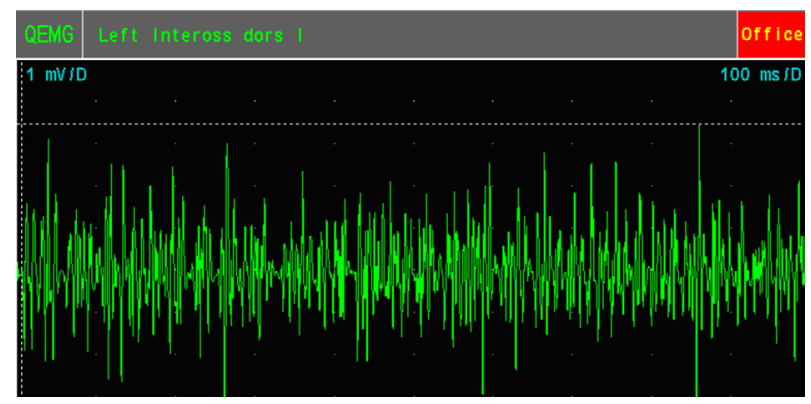

Figure 8 Postoperative recruitment of maximal voluntary contraction in left first Dorsal Int muscles.

Abbreviation: QEMG, quantitative electromyography.

\section{Pulmonary function test}

The results after cell-based comprehensive therapy (February 8, 2010) were better than before (January 13, 2010) and are presented in Table 5 .

\section{Follow-up}

After the patient was discharged, we followed-up the patient by email or phone call every 2 months up to the end of March 2014. The patient's condition was excellent with no pain and he walked well.

\section{Discussion}

Cell-based neurorestorative therapy was studied by carrying out basic empirical researches and clinical researches. 
Table 5 The results of pulmonary function before and after the treatment

\begin{tabular}{|c|c|c|c|c|c|c|c|c|c|c|c|c|}
\hline Indicators & $\begin{array}{l}\text { VC } \\
\text { (L) }\end{array}$ & $\begin{array}{l}\text { FVC } \\
\text { (L) }\end{array}$ & $\begin{array}{l}\text { FEVI } \\
\text { (L) }\end{array}$ & $\begin{array}{l}\text { FEVI/FVC } \\
\text { (\%) }\end{array}$ & $\begin{array}{l}\text { MMEF } \\
(\mathrm{L} / \mathrm{s})\end{array}$ & $\begin{array}{l}\text { PEF } \\
(\text { L/s) }\end{array}$ & $\begin{array}{l}\text { MVV } \\
\text { (L/min) }\end{array}$ & $\begin{array}{l}\text { MV } \\
\text { (L/min) }\end{array}$ & $\begin{array}{l}\text { MEP (cm } \\
\left.\mathrm{H}_{2} \mathrm{O}\right)\end{array}$ & $\begin{array}{l}\text { MIP (cm } \\
\left.\mathrm{H}_{2} \mathrm{O}\right)\end{array}$ & $\begin{array}{l}\text { In Rint (cm } \\
\left.\mathrm{H}_{2} \mathrm{O} /(\mathrm{L} / \mathrm{s})\right)\end{array}$ & $\begin{array}{l}\text { Ex Rint (cm } \\
\left.\mathrm{H}_{2} \mathrm{O} /(\mathrm{L} / \mathrm{s})\right)\end{array}$ \\
\hline Before & 2.55 & 2.4 & 2.16 & 90 & 3.35 & 4.85 & 74.1 & 10.26 & 57.6 & 29 & 2.77 & 3.48 \\
\hline After & 2.64 & 2.5 & 2.35 & 94 & 3.64 & 7.59 & I I 2.4 & 12.24 & 77.3 & 68.8 & 3.52 & 3.66 \\
\hline
\end{tabular}

Abbreviations: VC, vital capacity; FVC, forced vital capacity; FEVI, forced expiratory volume in one second; MMEF, maximal mid-expiratory flow; MVV, maximal ventilatory volume; MV, minute ventilation; MEP, maximal expiratory pressure; MIP, maximal inspiratory pressure; In Rint, inspiratory resistance; Ex Rint, expiratory resistance; s, second; L, liter; min, minutes.

In animal model and patients, it proved effective for central nervous system diseases. ${ }^{25,26}$ It was applied for olfactory ensheathing cells, neural progenitor cells, stromal cells, Schwann cells, and so on. ${ }^{12}$ Also, pathways of cell therapy include intracerebral, intraspinal, intravenous, intramuscular, intrathecal injection, and so on. Basic and clinical researches performed by our team gave some good results. ${ }^{10,27}$

The patient discussed here had sensory abnormalities, except the symptoms and signs of PPS. Reviewing the literature reports, we find the description "The main symptoms of PPS are slowly progressive muscle limbs paresis with muscle atrophy, joints pain, paresthesia" by Pastuszak et $\mathrm{al}^{28}$ of Poland. There may be a few cases of PPS that possibly have paresthesia. This is just our explanation; we cannot state that we know the exact reason of this.

The potential mechanisms for functional recovery of PPS by cell-based neurorestorative therapy are as follows: implanted cells may secrete some neurotrophic factors for the impaired neurons ${ }^{29}$; implanted olfactory ensheathing cells may promote axonal regeneration and remyelination ${ }^{30,31}$; moreover, it is possible that the implanted cells may change the internal neuromuscular environment and stimulate autologous stem cells to secrete factors. ${ }^{32,33}$

This is the first clinical report of a PPS patient treated by cell-based neurorestorative therapy, which showed some promising results. Although the patient received routine treatments and rehabilitation therapy after he was diagnosed of PPS and before undergoing treatment from us, his condition got worse with time. It was exciting that the patient recovered to be able to take care of himself again, walk normally, and had got relieved from pain during the 4-year period after our treatment. It is too early to conclude that cell-based neurorestorative therapy can be a routine treating method for PPS, but it is our duty to share this finding with the doctors and patients whose concern is treatment progression for PPS.

\section{Disclosure}

The authors report no conflicts of interest in this work.

\section{References}

1. Willén C, Thorén-Jönsson, AL, Grimby G, Sunnerhagen, KS. Disability in a 4-year follow-up study of people with post-polio syndrome. $J$ Rehabil Med. 2007;39(2):175-180.
2. Corrêa JC, Rocco CC, de Andrade DV, Peres JA, Corrêa FI. Electromyographic and neuromuscular analysis in patients with post-polio syndrome. Electromyogr Clin Neurophysiol. 2008;48(8):329-333.

3. Trojan DA, Cashman NR. Post-poliomyelitis syndrome. Muscle Nerve. 2005;31(1):6-19.

4. Gonzalez H, Sunnerhagen KS, Sjöberg I, Kaponides G, Olsson T, Borg $\mathrm{K}$. Intravenous immunoglobulin for post-polio syndrome: a randomised controlled trial. Lancet Neurol. 2006;5(6):493-500.

5. Oncu J, Durmaz B, Karapolat H. Short-term effects of aerobic exercise on functional capacity, fatigue, and quality of life in patients with postpolio syndrome. Clin Rehabil. 2009;23(2):155-163.

6. Kalkman JS, Schillings ML, Zwarts MJ, van Engelen BG, Bleijenberg $\mathrm{G}$. The development of a model of fatigue in neuromuscular disorders: a longitudinal study. J Psychosom Res. 2007;62(5):571-579.

7. Boyer FC, Tiffreau V, Rapin A, Laffont I, Percebois-Macadré L, Supper C, Novella JL, Yelnik AP. Post-polio syndrome: Pathophysiological hypotheses, diagnosis criteria, medication therapeutics. Ann Phys Rehabil Med. 2010;53(1):34-41.

8. Chen L, Huang HY. [Neurorestoratology: new concept and bridge from bench to bedside]. Zhongguo Xiu Fu Chong Jian Wai Ke Za Zhi. 2009;23(3):366-370.

9. International Association of Neurorestoratology. Beijing declaration of international association of neurorestoratology (IANR). Cell Transplant. 2009;18(4):487.

10. Liu K, Li Y, Wang H, et al. The immunohistochemical characterization of human fetal olfactory bulb and olfactory ensheathing cells in culture as a source for clinical CNS restoration. Anat Rec (Hoboken). 2010;293(3):359-369.

11. Huang H. Neurorestoratology, a distinct discipline and a new era: a brief introduction to the first IANR section. Cell Transplant. 2010;19(2):129-131.

12. Huang H, Chen L, Sanberg P. Cell therapy from bench to bedside translation in CNS neurorestoratology era. Cell Med. 2010;1(1): $15-46$.

13. Sanberg PR, Eve DJ, Willing AE, et al. The treatment of neurodegenerative disorders using umbilical cord blood and menstrual blood-derived stem cells. Cell Transplant. 2011;20(1):85-94.

14. Huang HY, Chen L, Xi H, et al. Fetal olfactory ensheathing cells transplantation in amyotrophic lateral sclerosis patients: a controlled pilot study. Clin Transplant. 2008;22(6):710-718.

15. Huang HY, Xi HT, Chen L, Zhang F, Liu YC. Long-term outcome of olfactory ensheathing cell therapy for patients with complete chronic spinal cord injury. Clin Transplant. 2012;21(S1):S23-31.

16. Tetzlaff W, Okon EB, Karimi-Abdolrezaee S, et al. A systematic review of cellular transplantation therapies for spinal cord injury. $J$ Neurotrauma. 2011;28(8):1611-1682.

17. Chen L, Huang HY, Xi HT, et al. Intracranial transplant of olfactory ensheathing cells in children and adolescents with cerebral palsy: a randomized controlled clinical trial. Cell Transplant. 2010;19(2): 185-191.

18. Chen L, Chen D, Xi HT, et al. Olfactory ensheathing cell neurorestorotherapy for amyotrophic lateral sclerosis patients: benefits from multiple transplantations. Cell Transplantat. 2012;21(Supp 1):S65-77.

19. Bohbot A. Olfactory ensheathing glia transplantation combined with laserponcture $\AA$ in human spinal cord injury: results measured by electromyography monitoring. Cell Transplant. 2010;19:179-184.

20. People's Republic of China, Ministry of Public Health, Science and Technology Bureau, 1991. Instruction for prepare and clinical application of the aborted human fetuses (91-006). 
21. Xi HT, Chen L, Huang HY, et al. Preliminary report of multiple cell therapy for patients with multiple system atrophy. Cell Transplant. 2013;22 (Suppl 1):S93-S99.

22. Chen L, Xi HT, Huang H, et al. Multiple cell transplantation based on an intraparenchymal approach for patients with chronic phase stroke. Cell Transplant. 2013;22 (Suppl 1):S83-S91.

23. Ditunno JF Jr. American spinal injury standards for neurological and functional classification of spinal cord injury: past, present and future. 1992 Heiner Sell lecture of the American Spinal Injury Association. $J$ Am Paraplegia Soc. 1994;17(1):7-11.

24. International Association of Neurorestoratology. Clinical application of the principle of cell transplantation in neurorestoratology. Chinese $J$ Reparat Reconstruct Surg. 2008;22(8):1021-1023. Available from: http://www.ianr.org.cn/images/SCI-FRS(Seeking\%20Suggestions).pdf.

25. Okano H. Neural stem cells and strategies for the regeneration of the central nervous system. Proc Jpn Acad Ser B Phys Biol Sci. 2010;86(4): $438-450$.

26. Orlacchio A, Bernardi G, Orlacchio A, Martino S. Stem cells: an overview of the current status of therapies for central and peripheral nervous system diseases. Curr Med Chem. 2010;17(7):595-608.
27. Huang HY, Chen L, Xi HT, et al. [Olfactory ensheathing cells transplantation for central nervous system diseases in 1,255 patients]. Zhongguo Xiu Fu Chong Jian Wai Ke Za Zhi. 2009;23(1):14-20.

28. Pastuszak Ż, Tomczykiewicz K, Stępień A. Post-polio syndrome - a case report. Pol Merkur Lekarski. 2015;39(229):37-39.

29. Wang F, Yasuhara T, Shingo T, et al. Intravenous administration of mesenchymal stem cells exerts therapeutic effects on parkinsonian model of rats: focusing on neuroprotective effects of stromal cell-derived factor-1 alpha. BMC Neurosci. 2010;11(1):52.

30. Blits B, Boer GJ, Verhaagen J. Pharmacological cell and gene therapy strategies to promote spinal cord regeneration. Cell Transplant. 2002;11(6):593-613.

31. Ramon-Cueto A, Valverde F. Olfactory bulb ensheathing glia: a unique cell type with axonal growth-promoting properties. Glia. 1995;14(3):163-173.

32. Meng J, Adkin CF, Arechavala-Gomeza V, Boldrin L, Muntoni F, Morgan JE. The contribution of human synovial stem cells to skeletal muscle regeneration. Neuromuscul Disord. 2010;20(1):6-15.

33. Yohn DC, Miles GB, Rafuse VF, Brownstone RM. Transplanted mouse embryonic stem-cell-derived motoneurons form functional motor units and reduce muscle atrophy. J Neurosci. 2008;19;28(47):12409-12418.
Journal of Neurorestoratology

\section{Publish your work in this journal}

The Journal of Neurorestoratology is an international, peer-reviewed, open access online journal publishing original research and review articles on the subject of Neurorestoratology. To provide complete coverage of this revolutionary field the Journal of Neurorestoratology will report on relevant experimental research, technological advances,
Dovepress

and clinical achievements. The manuscript management system is completely online and includes a very quick and fair peer-review system, which is all easy to use. Visit http://www.dovepress.com/testimonials. php to read real quotes from published authors. 